\title{
OPTIMISME DITINJAU DARI PENERIMAAN DIRI PADA REMAJA DI PANTI ASUHAN
}

\author{
Nurenzia Wini, Winida Marpaung, dan Sarinah \\ Fakultas Psikologi, Universitas Prima Indonesia \\ winieaurora@gmail.com
}

\begin{abstract}
Abstrak
Optimisme adalah suatu pandangan secara menyeluruh melihat hal yang baik dan berfikir positif. Umumnya remaja di panti asuhan memiliki sifat optimis yang rendah dan mudah putus asa. Sikap optimis dapat ditingkatkan jika remaja mampu menerima dirinya sendiri. Penelitian ini bertujuan untuk mengetahui hubungan antara penerimaan diri dengan optimisme. Hipotesis yang diajukan dalam penelitian ini adalah terdapat hubungan positif antara penerimaan diri dengan optimisme, dengan asumsi semakin tinggi tingkat penerimaan diri, maka akan semakin tinggi tingkat optimisme, dan sebaliknya. Subjek dalam penelitian ini adalah remaja yang tinggal di di Panti Asuhan LPI Markaz Al Ishlah Al Azziyah Banda Aceh sebanyak 118 orang dengan metode purposive sampling. Data diperoleh dari skala untuk mengukur optimisme dan penerimaan diri. Teknik analisis data yang digunakan dalam penelitian ini adalah Pearson Product Moment Correlation. Hasil analisis data menunjukkan koefisien korelasi sebesar 0,568 dengan $p=0,000(p<0,05)$ yang berarti ada hubungan positif yang signifikan antara penerimaan diri dengan optimisme. Hasil penelitian ini menunjukkan bahwa sumbangan yang diberikan penerimaan diri terhadap optimisme adalah sebesar 32,3 persen, selebihnya 67,7 persen dipengaruhi oleh faktor lain yang tidak diteliti.
\end{abstract}

Kata kunci: Optimisme, Remaja, Panti Asuhan, Penerimaan Diri.

\section{OPTIMISM IS REVIEWED FROM SELF ACCEPTANCE IN ADOLESCENTS IN ORPHANAGE}

\begin{abstract}
Optimism is an overall view of seeing good things and positive thinking. Generally teenagers in orphanages have a low optimistic nature and are easily discouraged. Optimism can be improved if adolescents are able to accept themselves. This study aims to determine the relationship between self-acceptance and optimism. The hypothesis of this study states that there is a positive relationship between self acceptance and optimism, assuming that the higher the self acceptance is, the higher the optimism will be and conversely. The subjects of this study were adolescents orphanage in LPI Markaz Al Ishlah Al Azziyah Banda Aceh consisting of 118 subjects selected by using purposive sampling method. Data were obtained from a scale to measure self acceptance and optimism. The data analysis technique used in this study is the Pearson Product Moment Correlation. The results of data analysis showed a correlation coefficient of 0,568 with $0,000(p<0,05)$ which means there is positive relationship between self disclosure and resilience. The results of this study indicate that the contributions made by self acceptance to the optimism was 32,3 percent and the remaining 67,7 percent is influenced by other factors that are not examined.
\end{abstract}

Keywords: Optimism, Adolescents, Orphanage, Self Acceptance. 


\section{Pendahuluan}

Remaja merupakan masa transisi dari masa kanak-kanak menuju masa dewasa. Menurut Sarwono (2006), rentang usia remaja 14-24 tahun, mereka harus melewati tugas-tugas perkembangan. Tugas-tugas perkembangan masa remaja menurut Hurlock (dalam Ali \& Asrori, 2011) adalah mampu menerima keadaann fisiknya, mampu menerima dan memahami peran seks usia dewasa, mampu membina hubungan baik dengan anggota kelompok yang berlainan jenis. Selain itu tugas perkembangan remaja adalah mencapai kemandirian emosional, mencapai kemandirian ekonomi, mengembangkan konsep dan keterampilan intelektual yang sangat diperlukan untuk melakukan peran sebagai anggota masyarakat. Disamping itu juga remaja memiliki tugas untuk dapat memahami dan menginternalisasikan nilai-nilai orang dewasa dan orang tua, mengembangkan perilaku tanggung jawab sosial yang diperlukan untuk memasuki dunia dewasa, mempersiapkan diri untuk memasuki perkawinan serta memahami dan mempersiapkan berbagai tanggung jawab kehidupan keluarga.

Peran orang tua bagi remaja dalam melewati tugas perkembangan sangatlah penting, adanya kehadiran orang tua dan terpenuhinya kebutuhan serta penerimaan dari keluarga dapat membuat seseorang merasa bahwa dirinya diinginkan, dicintai, dihargai, dan diterima sehingga dia dapat menghargai dirinya sendiri. Perasaan aman dan kasih sayang yang diterima dari keluarga dapat membawa pada terbentuknya penerimaan diri yang baik pada remaja.

Pada kenyataannya tidak semua remaja dapat merasakan adanya kehadiran orang tua yang dapat membantu mereka dalam memenuhi tugas-tugas perkembangan, banyak pula remaja yang tidak dapat merasakan cinta dan kasih sayang dari orang tua mereka. Banyak remaja yang harus berpisah dan kehilangan orangtua karena berbagai alasan atau peristiwa tertentu, sehingga mereka harus menjalani hidup mereka tanpa kehadiran dan kasih sayang dari orang tua kandung mereka dan tinggal di panti asuhan.

Berdasarkan hasil penelitian yang dilakukan oleh Sudrajad bahwa, jumlah panti asuhan di seluruh Indonesia diperkirakan antara 5.000 sampai dengan 8.000 yang mengasuh sampai 500.000 anak dan diperkirakan merupakan jumlah panti asuhan terbesar di seluruh dunia. Panti asuhan tersebut sebagian besar diselenggarakan oleh masyarakat, terutama organisasi keagamaan, sedangkan Pemerintah Indonesia sendiri hanya memiliki dan menyelenggarakan sedikit dari panti asuhan tersebut (Kementrian Sosial Republik Indonesia, 2018).

Pada umumnya remaja panti asuhan memiliki deskripsi atau gambaran psikologis, seperti kepribadian yang inferior, pasif, apatis, menarik diri dan mudah putus asa(Hartini dalam Mazaya \& Supradewi, 2011). Oleh karena itu, remaja yang tidak memiliki pengembangan diri yang baik, tidak mampu bangkit dari masalah dan tidak percaya diri dengan kemampuan yang dimiliki dapat dikatakan bahwa seseorang itu tidak memiliki sikap optimis didalam dirinya. Sikap positif seperti memiliki keyakinan atas segala sesuatu dari segi yang baik dan menguntungkan. Orang yang selalu semangat berpengharapan baik dan bertekad untuk bangkit dalam setiap masalah yang dihadapinya dalam disiplin ilmu Psikologi dikenal sebagai optimisme.

Shapiro (2010) mendefiniskan optimisme adalah orang yang selalu berpengharapan (berpandangan) baik dalam menghadapi segala hal. Ketika berada dalam situasi yang sulit, orang optimis memandang bahwa kesulitan adalah batu pijakan untuk meraih hasil yang lebih baik. Orang optimis juga mampu mengukur kadar kemampuannya, dan memanfaatkan kemampuannya dengan maksimal untuk meraih apa yang dia inginkan. Ketika memiliki keinginan yang sulit dicapai, orang 
optimis tetap berusaha mencoba. Meski kemudian gagal, dia sudah cukup puas dengan usaha yang telah dilakukannya.

Optimisme mendorong individu untuk selalu berpikir bahwa sesuatu yang terjadi adalah hal yang terbaik bagi dirinya. Seligman (2006) menyatakan Optimisme adalah suatu pandangan secara menyeluruh, melihat hal yang baik, berpikir positif dan mudah memberikan makna bagi diri. Individu yang optimis mampu menghasilkan sesuatu yang lebih baik dari yang telah lalu, tidak takut pada kegagalan, dan berusaha untuk tetap bangkit mencoba lagi bila kembali gagal.

Seligman (2006), mengungkapkan optimisme memiliki 3 aspek, yaitu : (1) Permanence, orang yang optimis yakin bahwa kejadian negatif yang menimpanya bersifat sementara, sedangkan kejadian positif yang menimpanya bersifat lama atau permanen. (2) Pervasiveness, orang yang optimis yakin bahwa kegagalan yang terjadi karena sesuatu yang bersifat spesifik, sedangkan kesuksesan disebabkan oleh sesuatu yang bersifat universal. (3) Personalization, orang yang optimis yakin bahwa kesalahan itu dari faktor eksternal, dan kesuksesan berasal dari faktor internal.

Salah satu faktor yang mempengaruhi optimisme adalah penerimaan diri. Hasil penelitian dilakukan oleh Aidina., dkk (2013) bahwa terdapat hubungan positif antara penerimaan diri dengan optimisme menghadapi masa depan pada remaja di panti asuhan. Semakin tinggi penerimaan diri maka semakin tinggi optimisme menghadapi masa depan atau sebaliknya.

Selanjutnya Germer (2009) yang juga menyatakan bahwa penerimaan diri sebagai kemampuan individu untuk dapat memiliki suatu pandangan positif mengenai siapa dirinya yang sebenar-benarnya, dan hal ini tidak dapat muncul dengan sendirinya, melainkan harus dikembangkan oleh individu. Maslow (dalam Feist \& Feist 2009) mengemukakan bahwa penerimaan diri adalah seseorang yang memiliki ketenangan emosional dimana individu menerima diri apa adanya.

Supratiknya (1995) mengemukakan beberapa aspek penerimaan diri, yaitu: (1) Kerelaan untuk membuka diri. (2) Kesehatan psikologis, berkaitan dengan kualitas perasaan terhadap diri sendiri. (3) Penerimaan terhadap orang lain.

Penulisan ini memiliki tujuan yaitu untuk mengetahui hubungan antara penerimaan diri dengan optimisme pada remaja di panti asuhan. Manfaat praktis dari penelitian ini yaitu: (1) Bagi subjek penelitian, memberikan masukan kepada subjek agar ketika menghadapi peristiwa tersebut mampu membuat dirinya bangkit dengan keadaan yang sangat sulit dan menerima segala peristiwa yang sedang terjadi serta semangat dalam menghadapi cobaan yang sulit dan melanjutkan hidup kembali. (2) Bagi pengelola panti, Diharapkan hasil penelitian ini dapat dijadikan sebagai pedoman agar dapat membangkitkan optimis para subjek sehingga dapat bekerja sama dalam upaya meningkatkan penerimaan diri subjek menjadi lebih baik. Manfaat teoritis dari penelitian ini yaitu diharapkan dapat memperkaya dan memperluas wawasan serta wacana dalam psikologi sosial dan perkembangan, khususnya berkaitan dengan optimisme dan penerimaan diri.

\section{Metode Penelitian}

Metode penelitian yang digunakan adalah metode kuantitatif dan alat pengumpulan data yang digunakan adalah Skala Likert. Skala Likert disajikan dalam bentuk pernyataan yang bersifat favourable dan unfavourable dengan empat alternatif jawaban untuk setiap butir pertanyaan. Kriteria penilaian aitem favourable berdasarkan skala Likert adalah nilai (1) untuk jawaban Sangat Tidak Setuju (STS), nilai (2) untuk jawaban Tidak Setuju (TS), nilai (3) untuk jawaban Setuju (S), dan nilai (4) untuk jawaban Sangat Setuju (SS). Sedangkan kriteria penilaian untuk aitem unfavourable 
adalah nilai (1) untuk jawaban Sangat Setuju (SS), nilai (2) untuk jawaban Setuju (S), nilai (3) untuk jawaban Tidak Setuju (TS), dan nilai (4) untuk jawaban Sangat Tidak Setuju (STS). Skala Optimisme terdiri dari 29 aitem dengan 15 aitem favourable dan 14 aitem unfavourable. Skala ini mengacu pada teori yang diungkapkan Seligman (2006) yang meliputi 3 aspek, yaitu permanence, persasiveness, dan personalization . Skala Penerimaan terdiri dari 35 aitem dengan 17 aitem favourable dan 18 aitem unfavourable. Skala ini mengacu pada teori yang diungkapkan Supratiknya (1995) yang meliputi 3 aspek, yaitu pembukaan diri, kesehatan psikologis, dan penerimaan terhadap orang lain.

\section{Subjek Penelitian}

Pengambilan sampel dilakukan dengan menggunakan teknik purposive sampling. Purposive sampling adalah teknik sampling yang digunakan peneliti jika peneliti mempunyai pertimbanganpertimbangan tertentu di dalam pengambilan sampelnya atau penentuan sampel untuk tujuan penelitian (Azwar, 2014). Subjek penelitian ini adalah 118 remaja yang tinggal di LPI Dayah Markaz AI Ishlah Al Aziziyah Banda Aceh. Adapun karakteristik dalam penelitian ini, yaitu:

1. Laki-laki dan perempuan

2. Usia 12-18 tahun

3. Tidak memiliki orangtua dan tinggal di panti asuhan.

\section{Definisi Operasional}

Optimisme adalah dorongan individu untuk selalu berpikir bahwa sesuatu yang terjadi adalah hal yang terbaik bagi dirinya dan mampu menghasilkan sesuatu yang lebih baik dari yang telah lalu, tidak takut pada kegagalan serta berusaha untuk tetap bangkit mencoba lagi bila kembali gagal agar dapat sukses dalam mencapai tujuan yang diinginkan. Sedangkan Penerimaan diri adalah suatu keadaan dimana individu mampu menerima dirinya sendiri dan orang lain serta mampu dan mau untuk hidup dalam keadaan tersebut, memiliki penghargaan yang tinggi terhadap diri sendiri atau tidak bersikap sinis terhadap diri sendiri.

\section{Prosedur dan Analisa Data.}

Prosedur dalam pelaksanaan penelitian ini meliputi penyusunan skala yang akan digunakan, persiapan surat izin penelitian, uji coba skala untuk melihat validitas dan reliabilitas, pelaksanaan penelitian, dan analisis data.

Tahap pertama yang dilakukan adalah penyusunan skala optimisme dan penerimaan diri yang disusun oleh peneliti berdasarkan aspek-aspek optimisme yang dikemukakan oleh Seligman (dalam Ghufron \& Risnawati, 2011), dan aspek penerimaan diri yang dikemukakan oleh Supratiknya (1995). Skala ini kemudian diperiksa kembali oleh dosen pembimbing untuk melihat sejauh mana validitas isi dari skala yang dibuat. Setelah mendapatkan surat izin dari Fakultas Psikologi untuk melakukan penelitian maka peneliti melakukan persiapan untuk membuat skala yang akan dibagikan kepada remaja di Panti Asuhan.

Tahap kedua yaitu pelaksanaan penelitian dengan membagikan skala yang sudah valid dan reliabel. Pengambilan data dimulai dengan membagikan skala penelitian berupa skala Likert yang digunakan untuk mengungkap optimisme dan penerimaan diri. Skala untuk mengungkapkan optimisme 29 aitem dan skala untuk mengungkap penerimaan diri 35 aitem agar memudahkan pelaksanaan penelitian, skala untuk mengungkapkan variabel optimisme dan penerimaan diri di buat dalam 1 eksemplar, yang termasuk didalamnya (1) identitas subjek, (2) petunjuk pengisian skala, (3) skala optimisme, (4) skala penerimaan diri. Selanjutnya, memberi nilai dari setiap aitem dan skala. Pemberian nilai dilakukan dengan melihat kembali bobot dari setiap aitem dan kemudian 
memasukkan data dengan bantuan microsoft excel yang kemudian akan disalin ke SPSS untuk dilakukan analisis data untuk mengetahui hubungan antara kedua variabel.

Tahap ketiga adalah tahap analisa, analisis data yang digunakan dalam penelitian ini adalah korelasi Product Moment Pearson. Metode ini digunakan untuk mengetahui hubungan optimisme dengan penerimaan diri. Analisis korelasi ini menggunakan bantuan SPSS Statistics 17 for Windows.

\section{Hasil Penelitian}

Berikut adalah data deskriptif yang didapatkan dari setiap variabel.

Tabel 1.Hasil Analisis Deskriptif

\begin{tabular}{lcccc}
\hline \multicolumn{1}{c}{ Variabel } & Min & Max & Mean & SD \\
\hline Optimisme & 69 & 109 & 88,9 & 7,165 \\
Penerimaan Diri & 75 & 138 & 104,7 & 10.214
\end{tabular}

Sebelum melakukan uji hipotesis, terlebih dahulu dilakukan uji asumsi klasik untuk mengetahui ada tidaknya penyimpangan data yang diperoleh dari alat pengumpul data. Uji asumsi klasik yang digunakan dalam penelitian ini adalah uji normalitas sebaran dan uji linearitas hubungan. Uji normalitas sebaran menggunakan uji Kolmogorov Smirnov. Data terdisribusi normal jika $p>0.05$ (Priyanto, 2010).

Tabel 2. Uji Normalitas Sebaran

\begin{tabular}{cc}
\hline Variabel & Sig. \\
\hline Optimisme & 0.148 \\
Penerimaan Diri & 0.23 \\
\hline
\end{tabular}

Berdasarkan hasil pada tabel 2, tampak bahwa data yang didapatkan pada variabel optimisme dan variabel penerimaan diri terdistribusi normal. Selanjutnya, uji linearitas hubungan digunakan untuk mengetahui derajat hubungan antara variabel dalam penelitian ini sebagai syarat dilakukan pengujian analisis data korelasional Pearson Product Moment dengan tujuan untuk melihat apakah kedua variabel tersebut memiliki hubungan yang linear atau tidak. Kriteria uji linearitas hubungan adalah apabila nilai signifikansi $p<0.05$ maka dinyatakan memiliki derajat hubungan yang linear.

Tabel 3. Uji Linearitas Hubungan

\begin{tabular}{cc}
\hline Variabel & Sig. \\
\hline Optimisme & 0.000 \\
Penerimaan Diri &
\end{tabular}

Berdasarkan hasil pada tabel 3, dapat dikatakan bahwa variabel penerimaan diri dan variabel optimisme memiliki hubungan linear. Hal ini terlihat dari nilai sig sebesar 0.000 maka $p<0.05$, dapat disimpulkan bahwa kedua variabel memiliki hubungan linear dan telah memenuhi syarat untuk dilakukan analisis Pearson Product Moment Correlation. Setelah uji asumsi klasik diterima, selanjutnya dilakukan pengujian hipotesis. Hipotesis dalam penelitian ini adalah hubungan positif antara penerimaan diri dengan optimisme.

Tabel 4. Uji Korelasi Penerimaan Diri dengan Optimisme

\begin{tabular}{l|ccc}
\hline & Variabel & Optimisme & Sig. $(p)$ \\
\cline { 3 - 3 } & & $R$ & \\
\hline & Penerimaan Diri & 0,568 & 0.000 \\
\hline \multirow{3}{*}{16} & E-ISSN 2656-4173 & &
\end{tabular}


Berdasarkan hasil analisis korelasi antara penerimaan diri dan optimisme, diperoleh koefisien korelasi Pearson Product Moment sebesar 0.568 dengan sig sebesar $p=0.000(p<0.05)$. Hal ini menunjukkan bahwa adanya korelasi positif yang signifikan antara penerimaan diri dengan optimisme. (Priyatno, 2010). Dari hasil perhitungan tersebut, maka hipotesis yang diajukan dalam penelitian ini menunjukkan hubungan positif antara penerimaan diri dengan optimisme pada remaja diterima dan dapat dinyatakan bahwa ada hubungan positif yang signifikan antara penerimaan diri dengan optimisme.

Hasil ini sejalan dengan penelitian sebelumnya yang dilakukan oleh Aidina, dkk., (2013) dalam penelitiannya yang menguji hubungan antara penerimaan diri dengan optimisme pada 56 orang remaja di panti asuhan Banda Aceh. Penelitian ini menunjukkan adanya korelasi positif antara penerimaan diri dengan optimisme. Penelitian lain juga dilakukan oleh Hasan, dkk., (2012) yang menunjukkan adanya hubungan positif yang signifikan antara penerimaan diri dan dukungan emosional dengan optimisme.

\section{Uji Hipotesis}

Dari hasil analisis data pada 118 remaja yang menjadi subjek penelitian dapat diketahui bahwa 47 remaja (39\%) memiliki tingkat optimisme yang sedang, dan sisanya sebanyak 71 remaja (61\%) memiliki tingkat optimisme yang tinggi. Tabel 5 menunjukkan kategorisasi skor tingkat optimisme 118 remaja yang menjadi subjek penelitian.

Tabel 5. Kategorisasi Tingkat Optimisme Remaja

\begin{tabular}{lccc}
\hline Variabel & Kategori & Jumlah $(\mathrm{n})$ & Persentase \\
\hline Optimisme & Rendah & 0 & $0 \%$ \\
& Sedang & 47 & $39 \%$ \\
& Tinggi & 71 & $61 \%$ \\
\hline
\end{tabular}

Sedangkan dari 118 remaja yang memiliki penerimaan diri yang sedang sebanyak 62 remaja (74\%) dan 56 remaja (66\%) yang tingkat penerimaan dirinya berada di tingkat sedang. Tabel 6 menunjukkan kategorisasi skor tingkat penerimaan diri 118 remaja yang menjadi subjek penelitian.

Tabel 6. Kategorisasi Tingkat Penerimaan Diri Remaja

\begin{tabular}{cccc}
\hline Variabel & Kategori & Jumlah $(\mathrm{n})$ & Persentase \\
\hline Penerimaan Diri & Rendah & 0 & $0 \%$ \\
& Sedang & 62 & $74 \%$ \\
& Tinggi & 56 & $66 \%$ \\
\hline
\end{tabular}

Berdasarkan tabel 7 Model Summary Sumbangan Efektif dibawah ini, dapat disimpulkan dalam penelitian ini diperoleh koefisien determinasi $\left(R^{2}\right)$ sebesar 0.323 . Berdasarkan hasil tersebut, dapat disimpulkan bahwa sumbangan 32,3 persen penerimaan diri memengaruhi optimisme dan selebihnya sebesar 67,7 persen dipengaruhi oleh faktor-faktor lain yang tidak diteliti pada penelitian ini seperti konsep diri, regulasi diri, harga diri dan dukungan emosi. 
Tabel 7. Sumbangan Efektif

\begin{tabular}{cc}
\hline Variabel & R Square \\
\hline $\begin{array}{c}\text { Optimisme } \\
\text { Penerimaan Diri }\end{array}$ & 0.323 \\
\hline
\end{tabular}

\section{Pembahasan}

Penelitian pada 118 orang remaja di panti asuhan Banda Aceh, maka diperoleh hasil bahwa ada hubungan positif antara optimisme dengan penerimaan diri dengan koefisien korelasi product moment sebesar $r=0,568$ dan nilai $p$ sebesar $0,000(p<0,05)$ yang artinya semakin tinggi tingkat penerimaan diri remaja, maka akan semakin tinggi juga tingkat optimisme remaja, dan juga sebaliknya, semakin rendah tingkat penerimaan diri, maka akan semakin rendah optimisme.

Hasil dari penelitian ini diperoleh koefisien determinasi $\left(R^{2}\right)$ sebesar 0,323 . Berdasarkan hasil tersebut, dapat disimpulkan bahwa 32,3 persen variabel optimisme mempengaruhi penerimaan diri, dan selebihnya 67,7 persen dipengaruhi oleh faktor lain seperti konsep diri, regulasi diri, harga diri dan dukungan emosi.

Optimisme yang tinggi akan cenderung memberikan efek yang positif pada individu. Optimisme dipercaya dapat memberikan pandangan yang positif dan motivasi hidup yang kuat bagi siapa saja yang mengalami permasalahan, termasuk pada permasalahan penerimaan diri. Jika seorang remaja dapat menerima dirinya dengan baik maka ia akan optimis terhadap apa yang ia jalani kedepan.

Menyambung pernyataan di atas, peneliti juga telah melakukan sedikit wawancara kepada salah satu remaja. Menurut penuturan subjek, ia sering merasa sedih ketika mengingat orangtua nya yang telah tiada tetapi ia mencoba untuk tidak terus menerus larut dalam kesedihan, menerima keadaan dirinya sehingga dijadikan suatu motivasi agar mendapatkan hidup yang lebih layak.

Hal ini didukung oleh pernyataan Carver dan Scheier (2007) menyatakan individu yang optimis harus percaya diri dan memiliki ketetapan, bahkan jika kemajuan yang dihadapi sulit dan lambat. Penjelasan tersebut sejalan dengan tanda penerimaan diri yang disampaikan oleh Hamalik (1995) bahwa individu yang percaya diri sama halnya dengan mampu menerima kelebihan dan kekurangannya serta menerima celaan dan pujian. Keteguhan yang dimiliki individu yang optimis memperlihatkan keberaniannya mengambil resiko atas tindakan yang diambilnya dan tidak ragu atas pilihannya.

Hasil penelitian yang dilakukan oleh Aidina.,dkk., (2013) terhadap remaja putra dan putri yang usianya berkisar antara 15-18 tahun terdapat hubungan positif antara penerimaan diri dengan optimisme menghadapi masa depan pada remaja di panti asuhan. Semakin tinggi penerimaan diri maka semakin tinggi optimisme menghadapi masa depan atau sebaliknya. Hal ini menunjukkan bahwa peran penerimaan diri individu akan sangat membantu meningkatkan optimisme dalam dirinya sehingga individu dapat berpikir positif dan mudah memberikan makna bagi diri.

Pernyataan di atas juga sejalan dengan pengakuan salah satu subjek wanita yang diwawancara oleh peneliti. Subjek mengaku, ketika ia nyaman dengan dirinya rasa semangat akan muncul dari dalam diri sehingga membuat ia menjadi lebih memiliki tekad yang kuat untuk berhasil membanggakan orangtuanya yang telah tiada. 
Berdasarkan pembahasan di atas, maka dapat disimpulkan bahwa optimisme dapat meningkatkan penerimaan diri dengan cara memiliki pandangan yang positif, mempunyai tekad yang kuat, dan tidak takut akan kegagalan.

\section{KESIMPULAN}

Berdasarkan hasil-hasil yang telah diperoleh dalam penelitian ini, maka dapat disimpulkan sebagai berikut:

1. Ada hubungan positif antara penerimaan diri dengan optimisme dengan koefisien korelasi product moment sebesar $r=0,568$ dan nilai signifikansi $p$ sebesar $0,000(p<0,05)$ yang artinya semakin tinggi tingkat penerimaan diri, maka akan semakin tinggi juga tingkat optimisme, dan juga sebaliknya, semakin rendah tingkat penerimaan diri, maka akan semakin rendah optimisme.

2. Mean dari optimisme pada subjek penelitian remaja yang tinggal di LPI Dayah Markaz Al Ishlah Al Azziyah Banda Aceh, secara keseluruhan menunjukkan bahwa optimisme subjek lebih tinggi daripada populasi pada umumnya. Hal ini dapat dilihat dari nilai mean empirik sebesar 88,9 lebih tinggi dari nilai mean hipotetik sebesar 72,5. Berdasarkan kategori, maka dapat dilihat terdapat tidak ada yang memiliki tingkat optimisme yang rendah, 47 orang atau 40 persen memiliki tingkat optimisme yang sedang dan 71 orang atau 60 persen yang memiliki tingkat optimisme yang tinggi.

3. Mean dari penerimaan diri pada subjek penelitian remaja yang tinggal di LPI Dayah Markaz Al Ishlah Al Azziyah Banda Aceh, secara keseluruhan lebih tinggi dari populasi pada umumnya. Hal ini dapat dilihat dari nilai mean empirik sebesar 104,7 lebih tinggi dari mean hipotetik sebesar 87,5 .

4. Berdasarkan kategori, maka dapat dilihat tidak terdapat remaja yang memiliki penerimaan diri yang rendah, tetapi terdapat 62 orang atau 53 persen yang memiliki tingkat penerimaan diri yang sedang dan terdapat 56 orang atau 47 persen yang memiliki tingkat penerimaan diri yang tinggi.

5. Hasil Penelitian ini menunjukkan bahwa sumbangan yang diberikan variabel penerimaan diri terhadap variabel optimisme adalah sebesar 32,3 persen dan selebihnya 67,7 persen dipengaruhi oleh variabel lain yang tidak diteliti dalam penelitian ini seperti konsep diri, regulasi diri, harga diri dan dukungan emosi.

\section{SARAN}

Berdasarkan hasil dan kesimpulan penelitian di bagian sebelumnya, peneliti memberikan beberapa saran kepada beberapa pihak terkait dengan tujuan penelitian. Saran ini merupakan sebuah rekomendasi terkait dengan penggunaan data dan hasil penelitian ini sehingga dapat dimanfaatkan dengan optimal. Adapun saran-saran tersebut adalah sebagai berikut:

Disarankan remaja dapat meningkatkan rasa kepercayaannya bahwa harus terus berusaha dan tidak gampang menyerah ketika gagal agar dapat sukses mencapai cita-cita yang diinginkan melalui pergaulan, pengalaman, ataupun latihan.

Bagi pihak Panti Asuhan disarankan lebih memperhatikan kesejahteraan fisik serta psikologis anak panti dengan mengadakan seminar motivasi atau psikoedukasi untuk anak asuh agar memiliki pandangan yang positif terhadap hidupnya lebih baik kedepan. 
Kepada peneliti selanjutnya diharapkan agar dapat menyesuaikan waktu penelitian dengan panti asuhan dan mencari faktor lain, seperti konsep diri, regulasi diri, harga diri dan dukungan emosi.

\section{DAFTAR PUSTAKA}

Aidina,W., Nisa, H \& Sulistyani, A. (2013). Hubungan antara penerimaan diri dengan optimisme menghadapi masa depan pada remaja dipanti asuhan. Jurnal Psikohumanika Vol. VI No. 2. Diakses pada tanggal 5 Mei 2018 dari: http://setiabudi.ac.id/jurnalpsikologi/index.php

Ali, M. \& Asrori, M. (2011). Psikologi Remaja: Perkembangan Peserta Didik. Jakarta: PT BumiAksara.

Azwar, S. (2004). Reliabilitas dan Validitas. Yogyakarta: Pustaka Pelajar.

Azwar, S. (2014). Penyusunan Skala Psikologi. Yogyakarta: Pustaka Pelajar.

Carver, C. S. \& Scheier, M. (2007). Positive psychological assessment: Handbook of model and measures. In Lopez, S. J. dan Synder C. R. Washington, DC: American Psychological Assosiation.

Feist, J. \& Feist, G. J. (2009). Theories Of Personality, Seventh Edition. Singapore: McGraw-Hill.

Germer, C. K. (2009). The Mindful Path to self Compassion. New York: The Guilford Press. Diakses pada tanggal 5 April 2018 dari: http://www.amazon. com/The-Mindful-Path-SelfCompassion-Destructive/dp/1593859759

Ghufron, M. N \& Rini, R. S., (2010). Teori-teori Psikologi. Jogjakarta: AR-Ruzz Media.

Hamalik, O. (1995). Psikologi Remaja: Dimensi-dimensi Perkembangan. Bandung: Mandar Maju.

Hasan, N dan Rufaidah, E. (2013). Hubungan Antara Penerimaan Diri dan Dukungan Emosi dengan Optimisme pada penderita Diabetes cabang Surakarta. Jurnal ilmiah Psikologi. Vol. 2 No. 2. Diakses pada tanggal 5 Mei 2018 dari: http://candrajiwa.psikologi.fk.uns.ac.id/index.php/candrajiwa

Hurlock, E. B. (2008). Personality Development. New Delhi: McGraw-Hill.

Mazaya, N.K dan Supradewi. (2011). Hubungan konsep diri dengan kebermaknaan hidup pada remaja di panti asuhan. Jurnal Proyeksi, Vol. 6 Diakses pada tanggal 28 Juli 2018 dari: http://jurnal.unissula.ac.id index.php/proyeksi/article/view/251

Priyatno, D. (2010). Teknik Mudah dan Cepat Melakukan Analisis Data Penelitian dengan SPSS. Yogyakarta: Gaya Media.

Sarwono, S.W. (2006). Teori-teori Psikologi Sosial. Jakarta: PT Raja Grafindo Persada. 
Optimisme Ditinjau Dari Penerimaan Diri Pada Remaja di Panti Asuhan

Proyeksi Vol. 15 (1) 2020, 12-21

Seligman, M, E, P. (2006). Learned Optimism. New York: A Division of Random House, Inc.

Kemensos.go.id. (2018). Data Panti Asuhan. Diakses pada tanggal 6 Mei 2018 dari:

https://www.kemsos.go.id/search/node/data\%20panti\%20asuhan 